\title{
ORTAYA ÇIKIŞI VE UYGULANIŞIYLA MARShaLl PLANI
}

\author{
Çărı ERHAN*
}

\section{I-Planın Kökeni}

1947 başından itibaren A.B.D. ile Sovyetler Birlił̆i arasında savaş sırasında kurulan işbirliği ortamı yavaş yavaş ortadan kalktı. Amerikan kamuoyunda yayılan "kızıl tehlike" korkusu, halkın ve yöneticilerin Sovyetlere ilişkin düşüncelerinde büyük bir yön değişikliğine yol açtı. Bu büyük değişimin en büyük göstergesi 12 Mart 1947'de Başkan Harry Truman'ın Kongre'de yaptığı konuşmada, ilk kez, dünyanın iki ideolojik ilkeler dizisi arasında bölünmenin aşamasında olduğundan bahsetmesiydi. Bu tarihi konuşmasında Truman, komünist tehlikesi ile karşı karşıya bulunan Türkiye ve Yunanistan'a A.B.D.'nin 400 milyon dolarlık askeri yardım yapacağını açıklıyordu. ${ }^{1}$

Truman Doktrini'nin ilânıyla, soğuk savaşın dış ve iç gerekleri, karşılıklı olarak ideolojik ilkclere seslenme kılıfı alunda birbirlerini beslemeye başladı. Her ikisi de evrensel görüşler olan liberalizm ve komünizm, karşılıklı olarak birbirlerini dışladılar. Böylece, her iki taraf da, tüm dünyayı ideolojik kavganın politikasındaki üstünlükten aynlamayacağı bir arena olarak algılamaya başladı. Bir ülke ya Sovyet ya da A.B.D. bloğu içindeydi. Bunun ortası yoktu. ${ }^{2}$

Burada, soğuk savaşın dünyanın diğer bőlgelerini nasıl etkiledił̆i konusunu bir kenara bırakarak, bu çalışmanın asıl konusu olan Avrupa'ya ilişkin gelişmelere geçelim.

Amerikalılara göre, savaşın getirdiği büyük yıkım Avrupa'da kaos yaratmış ve bu nedenle komünistler ve dolayısıyla Sovyetler güçlenmişti. Sovyet yayılması karşısında, Avrupa maddi ve manevi olarak gü̧̧lendirilmeliydi. Avrupa, ekonomik olarak kendi ayakları üzerinde durabilirse, siyasi olarak da bağımsızlığını koruyabilirdi. A.B.D. bu noktada, Ingiltere, Almanya ve Fransa'yı ve sonra tüm Avrupa'yı artan bir biçimde siyasi

\footnotetext{
* A.U. Siyasal Bilgeler Fakültesi, Araştırma Görevlisi

${ }^{1}$ William McNeil, America, Britain and Russia: Their Co-operation ard Conflict (1941-1946), New York, Johnson Reprint Corporation, 1970, s.737.

${ }^{2}$ Paul Kennedy, Büyük Güçlerin Yükseliş̧ ve Düşüşlerl, ( çev. Birtane Karanakçı), Istanbul, Is Bankası Yayınları, 1989, s.437.
} 
ve ekonomik işbirliği içine sokınak, böylece bütünleşmiş bir Avrupa yaratarak Sovyet ilerlemesini durdurmak istiyordu. ${ }^{3}$

Savaş sonrasında Amerikan yőneticileri, iyimser bir tahminle, Avrupa'nın tamirinin sınırl iki taraflı kredilcrle, IMF yoluyla uygulanacak istikrar programlanyla ve son olarak BM ve Dünya Bankasi'nca finanse edilecek Yeniden Imar Planı ile yapılabileceğini düşünmekteydiler. Ancak, giderek artan ekonomik istikrarsızlıklar bunların dışında daha kapsımlı bir program geliştirilmesi ihtiyacını doğurdu. Ünlü Amerikalı düşünür Walter Li omann'a göre, Avrupa'daki ekonomik sonun aşılmazsa, bu en kısa sürede bütün dünyayı kiısa sürükleyebilirdi. Avrupa'da alınması gereken önlemler ekonomik bir birlik oluşturnak hedefine yönelik olmalıydı. En az Ödünç Verme ve Kiralama Yasası kadar kạısamlı bir program doğrultusunda yürütülmeliydi. Yine Lipmann'a göre Avrupa'ya tek tek ülkeler olarak' değil bir bütün olarak yardım edilmcliydi. Bu hem ekonomik bütünleşmeyi hızlandırır, hem de yeniden imarı kolaylaştırırdı. Tüm ülkeler t:k bir tamir programının tarafları olmalıydılar. ${ }^{4}$

Savaş sırasında, savaş sonrası düzen ve bütünleşmiş Avrupa'ya ilişkin münferid fikirler Washington'da ihtiyatla karşılanmıştı. Ancak, 1947 başından itibaren, ticaretin dünya çapında serbestleşmesi fikri çerçevesinde, Avrupa bütünleşmesi ya da en azından Avrupa'nın ekonomik bütünleşmesi fikri büyük destek görmeye başladı. A.B.D.'nin federal yapısına benzer, gümrük duvarlarından ve her türlü ticari sınırlandırmadan arındınlmış bir Avrupa'nın, ‘ncelikle Avrupa toplumunu daha müreffeh hale getirerek komünist yayılmasına karşı koruyacağı, sonra da Amerikan ekonomik çıkarlarının gerçekleşmesine hizmet edecr.ğine olan inanç giderek artt. 1947'de, Avrupa ekonomisinin giderek kötüleşmeye başlaması, savaş sırasında kurulan A.B.D.-Sovyetler Birliği ittifakının ortadan kalkmaya başlaması ve savaş sonrasına ilişkin nihai barış düzenlemelerine ilişkin miizakerelerin bir türlü sonuçlandırılamaması, Amerikan siyasetini plânlayanlar arasında bu fikrin iyice güçlenmesine yol açu. ${ }^{5}$

5 Mart 1947'dè, Türkiye ve Yunanistan'a ekonomik ve askeri yardım gơrüşmelerinin başlamasından kı.sa bir süre sonra, A.B.D. Dışişleri Bakanlığı Müsteşarı Dean Acheson, Dışişleri-Savaş-Donanma Bakanlıklan Koordinasyon Komitesi (StateWar-Navy Coordination Committe, (SWNCC)'nden Avrupa'ya yapılması düşüüulen yardımlar konusunda çalışmalar yapılmasını istedi. 11 Mart'da SWNCC bu konuyu görüşmck ve bir rapor hazırlamak için geçici bir kurul oluşturdu. Kurul, yardım yapılacak ülkeleri tespit edecek, yardımlara ayrılacak kaynak, yardımlann muhtemel kapsamı ve yardımların başarısız olmasından doğabilecek olumsuzluklar konularını inceleyecekti. Kurul ilk rapırunu 21 Nisan'da açıkladı. Raporda acil yardıma ihtiyaç duyan ve duymayan sekizer clevlet sayılıyordu. Komünizmin Bau avrupa için büyük bir tehlike olmaya devam ettiğine i iłaret edilen raporda, Sovyet yayılmasına karşı bir gụ̧̈ dengesi oluşturulabilmesi için öncelikle Ingiltere, Almanya ve Fransa arasında bir

3 Michàel Hogan, The Marshall Plan: America, Britain and the Reconstruction of Western Europe 1947-1952, New York, Cambridge University Press, 1983, s.22.

${ }^{4}$ Alexander De Conde, A History of American Foreign Policy, New York, Charles Scribner's Sons, 1971, s.675.

${ }^{5}$ Frank Block, The Origins of Economic Disorer, New York, McGraw Hill, 1971, s.85. 
işbirliğinin sağlanması gerektiği ifade ediliyordu. Komünist yayılmaya karşı en iyi cevabın, A.B.D.'nin yardımıyla Batı Avrupa'nın tamir edilip yeniden canlandırılması olduğu savunuluyordu. Ancak rapor, kapsamlı bir programa dayanak olma özelliği taşımıyordu. 6

SWNCC bünyesinde oluşturulan kurul ile aynı anda, Dışişleri Bakanlığı Siyaset Planlama Dairesi'nde de, ünlü stratejist George Kennan başkanlığında bir çalışma grubu oluşturulmuştu. Bir öncekine göre çok daha sistematik ve kapsamlı çalışmalar yapan bu grup ilk raporunu 23 Mayıs 1947'de Dışişleri Bakanı George Marshall'a sundu. Rapora göre, Amerika'nın yapacağı ekonomik yardımlar, daha fazla beklenilmeden yaz ortasında başlatılmalıydı. Yardımlar en fazla Batı Avrupa üzerinde yoğunlaştırılmalıydı. Amerika'nın lafı bırakıp icraata geçtiğini göstermek için, Avrupa'da yoğun ve enerjik bir faaliyet başlatılmalıydı. Raporda en çok üzerinde durulan ve "Avrupa'nın yeniden imarının dayandığı en büyük unsur" olarak nitelendirilen konu, "Avrupa için Kömür Programı" olarak özetlenebilccek, Ren vadisindeki kömür üretiminin restorasyonunun amaçlayan çalışmaydı. George Kennan'a göre, Ren bölgesinin ve dolayısıyla Almanya'nın yeniden imarı gerçekleştirilmeden, Batı Avrupa'nın yeniden imarı söz konusu edilemezdi.

23 Mayıs raporuna göre Avrupa'nın yeniden imarı iki aşamalı bir çalışmayı gerektirmekteydi. Birinci aşamada, ekonomik darboğazların hızla aşılacă̆ı kısa vadeli bir faaliyet, ikinci aşamada ise, Avrupa'nın ekonomik açıdan tamiri için uzun vadeli bir program öneriliyordu. Kısa vadede, Avrupa'ya güven verilmelí, Ren kömür üretimi yeniden başlatılmalı, bu kömürün tüketim alanlarına dağıtımı sağlanmalıydı. Uzun vadede, A.B.D. Avrupa işlerine asgari düzeyde kanışmalı, Avrupalıları kendi ayaklan üzerinde durduracak bir yardım programı geliştirildikten sonra bunun uygulaması Avrupalılara burakılmalıydı.

Bu iki kurul raporlarım hazırlarken, Dışişleri Bakanlığı Müsteşarı Dean Acheson da, Avrupa'nın yeniden iman konusunda kendi görüşlerini biçimlendirme çabası içindeydi. Acheson 8 Mayıs 1947'de Cleveland Mississippi'de yaptığı ünlü konuşmasında, A.B.D.'nin neden Avrupa'nın ekonomik durümunu düzeltmek zorunda olduğunu şöyle açıklıyordu:

"A.B.D.'nin üretimi ile dünyanın diğer bölgelerindcki üretim arasında çok büyük bir bağ vardır. Amerika'nın kendi çıkarları açısından, diğer "zor durumdaki" ülkelere yardım etmesi gerekmektedir. Dünyada istikrar sağlanmadan ve bazı dış ülkeler ekonomik olarak kendi kendilerine ekonomik olarak yeterli hale gelmeden, A.B.D. için uzun süreli bir barış ve refah söz konusu olamaz. Acilen çözülmesi gereken sorun, 16 milyarlık ihracat ile 8 milyarlık ithalat arasındaki farkı kapatmaktır. Amerika acilen, ithalatını ve Avrupa ülkelerindcki üretimi artırmalı ve Avrupalıların gelir düzeyinin artmasına yardımcı olmalıdır."8

${ }^{6}$ Charles L. Mee, The Marshall Plan: The Launching of Pax Americana, New York, Simon and Schuster, 1984, s.91-92.

7 Ibid. s. 93.

${ }^{8}$ Council on Foreign Relations, The United States in World Affairs: 1947-48, New York, Harper and Brothers, 1948, s.57 
Acheson'un konuşmasında açıkça görüldüğü gibi A.B.D., tekrar ayağa kalkmış, üreten, mal alıp satabilen bir Avrupa'ya ihtiyaç duymaktadır. Çünkü, savaş sonrasında, içeride, işsizlił̧in azalması, ödemeler dengesinin sağlanması ve ihracaun artınıması için dışarıda Amerikan ticaret ve yatırım hacminin arttınlması gerekmekteydi. Amerikan ticaret çevrelerinin en önemli müş̧erisi Avrupalılar olduğgna gơre, once bunların canlandırnlması ve savaşın getirdiği tahribaun ortadan kaldırılması gerekmekteydi. Avrupa bütünleşmiş bir dünya ticaret sisteminin içine sokulmalıydı. ${ }^{9}$

Ekonomik ihtiyaçların yanısıra, stratejik gereklilikler de Avrupa'nın yeniden imarını zorunlu kılıyordu. Amerikan siyaset plânlamacılarına göre, Avrupa düşman bir devletin veya devletler ittifakının denetimi aluna girmemesi gereken bir arz ve emek kaynağı, bir sanayi merkeziydi. Almanya'nın mağlubiyeti, Ingiltere ve Fransa'nın savaş sırasındaki tükenişleri, Orta ve Bat Avrupa'da bir güç boşluğu yaratmışt. Eğer A.B.D., güç dengesinin unsurlarını ekonomik ve siyasi olarak bir araya getirmezse, bu bölge Sovyet genişlemesine açık hale gelecekti.

Bunlann yanında, Avrupa'nın yeniden imarını amaçlayanlar, eski Avrupa devletler sisteminin yerine, kıtada kendi siyasi ve ekonomik çıkarlannı gerçekleştirmeye daha elverişli bir sistem kurmayı amaçlamaktaydılar. Bu en iyi, Amerikan federalizmi benzeri bir devlet yapısını Avrupa'ya uygulamak biçiminde olabilirdi. Çünkü, stratejik olarak, uluslarüstü kurumlar tarafindan denetlenen bütünleşmiş bir ekonomik düzen, Alman milliyetçiliğinin ve militarizminin kolayca denetim altına alınmasını sağlayabilir, Fransa'nın güvenlik ve ekonomik endiselerini gidererek Almanya'yı tamir edebilir ve dolayısıyla Sovyet ilerlemesinc karşı Batı Avrupa'da uygun bir güç dengesi yaratabilirdi. Amerikalılar, kendi ülkelerinde başardıklan, geniş bir iç pazarda, serbest pazar güçleri tarafından ve merkezî kurumların eşgüdümü ile oluşturulan alt yapı üzerinde bütünleş̧miş bir ekonomi yaratılması modelini Avrupa'ya ihraç etmek istiyorlardı. Nihai amaçları bir Avrupa Birleşik Devletleri kurmaktı. ${ }^{10}$

Yukanda sözünü ettiğimiz Moskova görüşmelerinden A.B.D.'nin istediği tarzda bir sonuç çımaması üzerine, Amerikalılar, bir daha geri adım atmamak koşuluyla, Sovyetler'in yardım ve müdahalesi olmadan bir programı uygulamaya koymaya kesin kez karar verdiler. Bu konudaki açıklamayı, Dışişleri Bakanı George Marshall 5 Haziran 1947'de Harvard Üniversitesi'nde verdiģi sőylevde yaptı. Marshall konuşmasında, Avrupa'nın içinde bulunduğu duruma kısaca değindikten sonra, Amerika'nın Avrupa uluslarını ortak bir imar plânı içinde bir araya getirme kararııı̆ı̆ını taşıdığını ifade etti. Marshall, Sovyetler Birliği de dahil olmak üzere tüm Avrupa ülkelerini bu plâna dahil olmaya davet ediyordu. ${ }^{11}$

Marshall'ın önerisinde üç nokta göze çarpmaktaydı. Birincisi, Truman Doktrini'nden farklı olarak, ekonomik tamir üzerine vurgu yapılmaktaydı. Yeni politika, açlık, fakirlik ve kaosla mücadeleye yönelmişti. Herhangi bir askeri yardım sőz konusu edilmemekteydi. Ikincisi, ulusal düzeyden, bölgesel düzeye (tüm Avrupa kıtası) çıkılmışu. Tek tek ülkeler değil, bir bölge söz konusu edilmekteydi. Daha önce Türkiye ve Yunanistan örneğinde görüldüğü gibi tek tek ülkelerle yardım ilişkisine giren A.B.D.,

\footnotetext{
${ }^{9}$ Hogan, op. cit., s. 27.

10 Ibid., s.429.

${ }^{11}$ Council...,op. cit., s.57-58.
} 
bu politikasını deģiştiriyordu. ${ }^{12}$ Öneride dikkati çeken son nokta ise, bu girişimi engellemeye kalkışacak olan hükümetler, siyasal partiler ya da grupların Amerika'nın direnişiyle karşılaşacağının ifade edilmesiydi. Bu sözler Sovyetler Birliği ve Bau Avrupa'daki komünist partilere yönelik açık bir ihtar niteliği taşımaktaydı. ${ }^{13}$

Marshall 5 Haziran'da, bundan sonra kendi adıyla anılacak plândan bahsederken, hiçbir plân çizmiyor, taahhüdler altuna girmiyordu. Tek yaptığı, yeni bir ekonomik işbirliğine giden yolu, basit bir öneriyle açmaktu. Aslında, o tarihte ortada tam bir plân da yoktu. Dışişleri Bakanı Marshall George Kennan'ın başkanlığındaki kurulun hazırladığı raporlara dayanarak bir çerçeve çiziyordu. Bu çerçevenin içi, ileriki aylarda Amerikalılar ve daha çok Avrupalılar tarafından doldurulacaktı. Marshall, Avrupalıların plâna doğrudan katılmasını istemekteydi. Çünkü, böylece ihtiyaçlar daha iyi karşılanabilir ve sorumluluk Avrupalıların üzerinde olacağından, biraraya gelip ortak bir ekonomi oluşturmalan ve anlaşmazlıklannı çözmeleri daha kolay olabilirdi.

Şimdi, A.B.D. plânın içeriǧini ve kapsamını Avrupalılarla görüşmeli ve onların katılımını sağlamak için çalışmalar yapmalıydı. Ancak, bir bütün olarak düşündüğümüzde tüm Avrupa devletleri plâna aynı iştiyakla yaklaşmadılar.

\section{II-Marshall Planı'na Avrupa Devletlerinin Tepkisi}

Marshall Planı'nın uygulayıcılan, Almanya'yı geniş bir Batı Avrupa içine almak ve bu ülkenin tamiratını, komşularının güvenlik endişelerini ortadan kaldırarak, yapmak istiyorlardı. Fransa, bu yaklaşıma en çok karşı çıkan ülke oldu. Fransa, Almanya'nın bölünmüş kalmasını ve Alman egemenliğine 1920 'lerde oldư̆u gibi sınırlamalar getirilmesini savunuyordu. Zaten, Fransız işadamı Jean Monnet'in adını taşıyan kendi plânlarını da gelişstirmişlerdi. Bu plânın tẹmelinde, Fransa'nın Alman endüstri bölgesini ilhak etmesi ya da en azından bu bölgenin kullanım haklarının Fransa'ya verilmesi yatuyordu. ${ }^{14}$

Yine de Fransız Başbakanı Ramadier ve Dışişleri Bakanı Bidault plânı doğrudan reddetmek yerine, Avrupalı ülkelerin temsilcileriyle görüşüp bir cevap vermeyi daha uygun buldular. Ramadier ve Bidault'nun bu uzlaşmaya yakın tavrı, ozzellikle komünistlerin yayın organları olan, L'Humanité, Franc-Tireur gibi gazetelerde şiddetle eleştirildi. Çünkü bunlar, Marshall Planını Amerikan emperyalizminin Avrupa'da yayılması için kullanılan bir araç olarak değerlendimekteydiler. ${ }^{15}$

Öte yandan, Ingiltere Dışişleri Bakanı Ernest Bevin, Marshall'ın 5 Haziran konuşmasından hemen sonra yaptığı açıklamada, "Marshall tekliflerini dơrt elle kabul ettiğini" bildirmişti. Ingiliz ve Fransız Dışişleri Bakanları, Plan karşısındaki birbirine pek yakın olamayan tutumlarına karşın, Avrupa devletlerinin bu konuda verecckleri ortak

12 Cabell Phillips, The Truman Presidency, New York, The Macmillan Company, 1966, s.181.

${ }^{13}$ Türkkaya Ataöv, "Marshall Planinnindan NATO'nun Kuruluşuna Kadar Soğuk Harp", A.Ũ.

S.B.F. Dergisi, C:XXIII, No:3 (1968), s.277.

${ }^{14}$ Hogan, op. cit., s.20.

15 Mee, op. cit., s.121. 
cevabı organize ctme işinde birlikte hareket etme karan aldılar. Avrupa'daki diğer büyük müttefik Sovyetler Birliği'nin Dışişleri Bakanı Vyacheslav Molotov'un da katılımıyla, ü̧̧ dışişleri bakanı, 27 Haziran 1947'de Paris'te bu konuyu görüşmek üzere biraraya geldi.

Molotov, Marshall Planı'nın Avrupa'yı Amerikan denctimine sokacağı endişesini taşımakta ve kabul edilemez bulmaktaydi. Zaten, 6 Haziran'dan itibaren Sovyetler Birliği'nin resmi yayın organı Pravda, Plan aleyhinde yayınlar yapmaya başlamışı. Molotov'un tutumu üzerine, Paris görüşmeleri ortak bir karara varılamadan sonuçlandı.

Paris görüşmelerinden iki gün sonra, Ingiliz ve Fransız Dışişleri Bakanları, tspanya dişındaki tüm Avrupa devletlerine, Plan konusunda yapılacak genel bir konferansa katulmalan için davette bulundu. 14 Avrupa ülkesi bu çağnnya olumlu cevap verdi. Son ana kadar konferansa katılma niyeti taşıyan Doğu Avrupa ülkeleri ise, Sovyctler Birliği'nin baskılanyla bu istcklerini gerçekleştiremediler. Dolayısıyla, Plan başlangıçtan itibaren, Doğu-Batu arasındaki uçurumu dèrinleştirdi. ${ }^{16}$.

12 Temmuz 1947'de, Paris'te Quai d'Orsay'da biraraya gelen, Avusturya, Danimarka, Yunanistan, Izlanda, Irlanda, ttalya, Lüksemburg, Hollanda, Norveç, Portekiz, Isveç, Isviçrc, Türkiyc, Ingiltere, Fransa temsilcileri, Avrupa'nın acil ihtiyaçlarını belirlemek ve karşılamak için, Avrupa Ekonomik Işbirliği Konferansı (Conference of Europan Economic Co-operation, CEEC) adında bir örgüt kurdular. Avrupa uluslạn daha önce hiçbir ortak girişim için bu kadar çok katılımla biraraya gelmemişti. ${ }^{17}$

Kanşı̧k ckonomik sorunlarla yüzyüze bulunan katılımcılar öncelikle siyasi amaçlarmı ortaya koydular. Tümdengelim metoduyla, siyasi dileklerinden, ekonomik ihtiyaçlanna doğru bir gidiş takip ettiler. Siyasi gerçeklerden hareket edip, siyasi bir yapıya ulaşmak yerine, istedikleri siyasi yapıdan harcket edip, ona siyasi gerçekleri uydurmak yolunu seçtiler. Tabii ki, ekonomik gerçckler, bu kararları etkilcyecekti. Ancak, hiçbiri ekonomik gerçeklerden yola çıkmak istemiyordu.

Mesela, Ingiltere içinde bulunduğu ekonomik durumun kötülüğünün farkında olmasına rağmen bunu açıkça kabullenmeye yanaşmıyordu. Ingilizler Marshall Planı karşısında bir ikilem yaşıyorlardı. Ekonomilerini tekrar rayına oturtabilmek ve Commonwealth içinde liderliklerini sürdürebilmek için Amerikan ekonomik yardımına ihtiyaç duyuyorlardi. Ancak bu destck kendi isteklerini karş̧layacak düzeyde de ğildi. Ötc yandan, Amerikalılara göre, para konvertibilitesi, ticari serbestlik gibi konular, Avrupa'da ekonomik istikrar ve büyümeye giden yolun başında bulunuyordu ki, Ingiltcre böyle bir düzene dahil olmaya hazır değildi. Ayrıca, Ingiltere, Amerika ile özel ikili ilişkileri olan bir devlet olarak, sıradan bir Avrupa ülkesi gibi görülmek istemiyordu. Sonuçta Ingiliz Dışişleri Bakanı Bevin, Ingiltere'nin Plan'ı destekleyeceğini fakat ekonomik yükümlülükler altına girmeyeceğini açıkladı. ${ }^{18}$ Ancak, ileriki günlerde, ekonominin

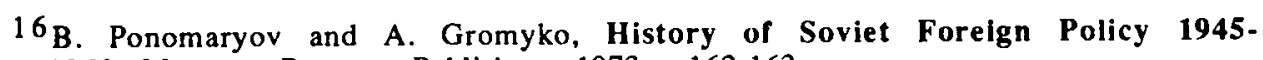
1970, Moscow, Progress Publishers, 1973, s.162-163.

17 Mee, op. cit., s.142.

18 Amerika'nın hedeflediğinin aksine uluslarüstü bir denetim mekanizmasının gözetimine girmek istemeyè Ingiltere, $1949^{\circ} \mathrm{da}$ sterlinin değerini korumak için, konvertibiliteyi dondurunca, A.B.D.'nin ekonomik olarak bütünleşmiş bir Avrupa için beslediği ümitler 
giderek daha da kötüleşmesi ve ơzellikle 1947-48 kışının çok kőtï geçmesi Ingilizlerin tutumunu biraz daha yumuşatu. 19

Diğer yandan, Plan'ın başanya ulaşması için kilit kֵonumda bulunan Fransa, Almanya sorunu ve kendi iç ekonomik problemleri nedeniyle, A.B.D.'nden gelen yoğun bir baskıyla karşıı karşıyaydı. Amerikalılar, Fransa'nın, Almanya'nın tekrar sınaileşmesine izin vermesini istiyor; bunun Avrupa'nın yeniden inşaında çok önemli bir unsur oldugunu savunuyorlardı. Fransızlar ise bu isteklere karşı çok inatçı bir tutum içine girmişlerdi.

CEEC Paris'te çalışmalarına devam ederken, 21 Temmuz 1947'de A.B.D. Dışişleri Bakanı Marshall, Fransa Dışişleri Bakanı Bidault'ya, Almanya'nın tamiri konusunda, Ingiltere'nin de katılacağı bir toplantı yapmayı önerdi. Çünkü Fransızlar Monnet Planı'nda öngörülen yıllık 12 milyön ton çelik üretimini tehlikeye düşürdüğ̈ü için A.B.D ile Ingiltere arasında kabul edilen Sanayi Düzeyi programına karşı çıkıyorlardı. Ancak, Londra'da 12 Ağustos'ta başlayan üçlü görüşmelerde taraflardan hiçbiri istediği sonucu alamadi. Bunun üzerine Bizonia'da 1947 Ağustos'undan itibaren Sanayi Düzeyi programı uygulanmaya başladı. Fransızlar ise kendi bölgelerinde bu programı uygulatmadılar. Aynı konuda, 1947 ve 1948 boyunca, Berlin, Paris, Londra ve Washington'da yapilan görüş̧melerde de sonuç sağlanamadı. Ancak, A.B.D.'nin Marshall Yardımları çerçevesinde Fransa'ya verdiği ekonomik destek sayesinde bu ülkenin inadı kırıldı. ${ }^{20}$

Yine CEEC toplantilan devam ederken, 27 Temmuz'da, Bidault, Molotov ve Bevin bir kez daha biraraya geldiler. Molotov'a göre, Avrupalılar A.B.D.'nin plânının tam olarak ne olduğunu bilmemekteydi. Dolayısıyla, A.B.D. şu sorulara cevap vermeliydi:

1-A.B.D.'nin Avrupa'nın tamiri için verecẹ̆i paranın kesin miktanı neydi?

\section{2-A.B.D. Kongresi böyle bir krediyi onaylayacak mıydı?}

Ingiliz. Dışişleri Bakanı Ernest Bevin, Molotov'a, demokrasilerde kimsenin yasamaya karışamayacağını, dolayısıyla Kongre'nin tutumunun şimdiden belli olamayacağını; A.B.D.'nin halihazırda belirlediği bir miktar olmadığını, bu miktarı Avrupalıların isteklerine göre tespit edeceğini bildirdi. Toplantya ara verildiğinde, Ingiliz ve Fransizlar, bir telgrafla Washington'a durumu ve Sovyetlerin "engelleyici" ve "geciktirici" politikalarnna izin verilmeyeceğini bildirdiler.

Öğleden sonraki oturumda Molotov, Sovyetler Birliği'nin Plana katılmayacağını resmen açıkladı. Çünkü, ona görc Avrupa devletlerinin kaynaklarının miktarının araşurılması onların egemenliğini zedelcyecekti. Amerikan kredilerinin Avrupa'nın iktisadi olarak tedavi edilmesi için değil, bazı Avrupa ülkelerini diğerlerine karşı biraraya

suya důşme aşamasına geldi. Ancak iki ülke liderlerinin yaptığı görüşmelerden sonra, Ingiltere sterlingi devalue etmeyi kabul etti. Ayrıca, Avrupa'da serbest ticarete yönelik çekincelerini de kaldırdı.

19 Mee, op.cit., s. 170

20 Idem. 
getirmek maksadını güttuiğủ görüşünü savunan Molotov, Ingiltere ve Fransa'yı Plan'a destek vermemeleri konusunda uyard. ${ }^{21}$

Sovyetler Birliģi, Marshall Planı'nı, Bau'nın II. Dünya Savaşı oncesinde Dơ̆u Avrupa ülkeleriyle kurduğu bir tür sömürge ilişkisini yeniden tesis etmeye yönelik bir program olarak değerlendirmekteydi. Doğu Avrupa ülkelerinin Plan'a katılmamalanyla, bu pazar Batı'nın elinden kaçmış sayılacaktu. Dogu Avrupa ülkeleri birer hammadde ihracatçısı ve mamul madde ithalatçısı haline getirilmeden, Plan'ın başarıya ulaşması imkansızdı. Marshall Planı'nı bu mantık içinde değerlendiren Sovyetler Birliği için Plan gerçek bir tehlikeydi. Ancak, Sovyetlerin boyle bir korku içinde olduğunu bilmeyen Bat kamuoyu, Molotov'un Paris toplantılarından aynlışını, bir baltalama eylemi olarak yorumlamı̧ıtı. 22

Aslında, A.B.D. yönetimi Sovyetler Birliği'nin Plan'a katılımı durumunda "bozgunculuk" yapacağın düşünmekte ve bunu istememekteydi. Ancak, bu düşüncesini açık açık ifade etmekten de çekinmekteydi. Sonuçta, Sovyetler'in katılmama kararı ile, Truman yönetimí rahat bir nefes ald.

Ancak, Truman'ın bu rahatlaması da çok uzun sürmedi. Çünkü, Plan dışında kalmakla beraber, Sovyetter Birliği Bau ve Doğu Avrupa ülkelerinde kendi ideolojisini yaymak için yaptığı çalışmaları yoğunlaşurdı. Fransa ve ltalya'nın Marshall Yardımlan programından çıkmalan için, bu ülkelerde çok büyük çapta iş̧i grevleri düzenlettirdi.

Molotov'un Paris toplantısını 2 Temmuz'da terk etmesinden hemen sonra, Sovyetler Birliği 10 Temmuz'da Bulgaristan, 11 Temmuz'da Çekoslavakya, 14 Temmuz'da Macaristan, 25 Temmuz'da Yugoslavya, 4 Ağustos'ta Polonya ve 26 Ağustos'ta Romanya ile ikili ticaret anlaşmaları yaptı. Doğu Avrupa bir ekonomik birliğe doğru gidiyordu. Bu ikili anlaşmalardan kısa bir süre sonra da yedi Avrupa ülkesi kendi aralarında Komünist Istihbarat Bürosu (Cominform)'nu kurdular. ${ }^{23}$

Tekrar Paris toplanulanına dönersek görüyoruz ki, A.B.D. toplantılara katılan Avrupa ülkelerinden Ingiltere aracılı̆̆ıla bazı şeyler istemekteydi. Öncelikle, katılımcılar, ekonomik ihtiyaçlarını akılıı bir biçimde ortaya koymalıydılar. A.B.D.'nin vereceği para, bir program çerçevesinde, dört yıllık bir süre içinde yavaş yavaş kullanılmalıydı. Uzun vadeli plânlar değil, acil ihtiyaçlanı karşılayacak kısa vadeli plânlar yapılmalıydı. Ikinci olarak, Avrupa ülkeleri paralarını istikarara kavuşturmalı, mali yapılannı düzene sokmalıydılar. Bu yolla ileride, kendi aralarında ticari engelleri kaldırıp, gümrük birliği sağlamalıydılar. Úçüncü olarak, hazırlayacakları raporda, ihtiyaç duyduklan kömür, petrol vb. hammadde miktarına, mevcut üretim durumlanına, üretim miktarının artırılmasına ilişkin önerilere, gıda, çelik, ulaşım araçlanı ve sanayi düzeyini belirten açıklamalara yer vermeliydiler. Son olarak, katılımcılar bu unsurları gerçekleşirebilecek bir örgütlenme içine girmeliydiler. ${ }^{24}$

21 Ponomaryov and Gromyko, op.cit., s.164.

22 Ataöv, op.cit., s. 281 .

${ }^{23}$ Idem.

24 Mee, op.cit., s. 189 . 
Paris'teki toplantıları izleyen George Kennan'a göre, burada Avrupa'nın yeniden inşaı için tatminkâr bir plân oluşturulması mümkün gözükmüyordu. A.B.D. katılımcılann, Avrupa problemlerine orijinal ve dört dörtlük bir yaklaşım gelişirmelerini beklememeliydi. Zira, toplantıya katılanların hiçbiri kendi ülkelerinde gü̧̧lü bir siyasi desteğe sahip değildi. Bu nedenle, bazı konularda mütereddid davranıyorlardı. Uzun görüşmelerden sonra, CEEC 22 Eylül 1947'de, Plan'in içeriği konusundaki raporunu hazırlayıp A.B.D.'ne sundu. Bundan sonrasi, A.B.D.'ndeki teknik uzmanlara ve Kongre'ye kalıyordu. 25

\section{III-Marshăll Planı'nın Uygulanması ve Sonuçları}

Plan'da yer alacak ülkelerin hazırladıklan rapor doğrultusunda, Amerikalı teknik ve siyasi uzmanlar yaklaşık iki ay süren bir çalışma yaptılar. Bu çalışma sonucunda, Avrupalıların istediği miktar olan 22 milyar dolar, yaklaşık \%22 oranında kısılarak, 17 milyar dolara indirildi. Bu indirime rağmen, Başkan Truman Plan'ı Kongre'ye sundư̆unda, önemli sayılabilecek miktarda Kongre üyesi, çok pahalı olduğu gerekçesiyle Plan'a muhalefet etti. Muhaliflere göre "Sam Amca, savaş sırasında ve sonrasında yeteri kadar Noel Baba'lık yapmıștı. Yeni bir yardım paketi hem gereksizdi, hem de zor durumdaki Amerikan ekonomisine ek yük getireceğinden zararlıydı". ${ }^{26}$

Bu muhalefete rağmen, Plan Amerikan kamuoyunda büyük bir desteğe sahipti. Tarım, işçi ve sanayi temsilcileri Plan lehinde açıklamalar yapmaktaydı. Basın da Plan'ı desteklemekteydi. Bir yandan da, Avrupa'daki olaylar Plan lehine gelişiyordu. 1948'de Çekoslovakya'da, demokratik yönetimi deviren komünistler iktidara gelmişti. 18 Nisan'da ftalya'da yapılacak seçimleri komünistlerin kazanması uzak bir ihtimal olarak gőrünmüyordu. Bütün bu gelişmeler, Kongre üyelerinin çoğunun Plan'ın yanında yer almasına yol açt. Senato, 20 Mart 1948'de, 69'a 17 ve Temsilciler Meclisi, 31 Mart'ta 329'a karşı 74 oy ile tasarıyı kabul ederek yasalaştırdı. Başkan Truman da, ttalyan seçimlerinin hemen arefesinde, 3 Nisan 1948'de yasayı onaylayarak yürürlüğe soktu. ${ }^{27}$

Marshall Planı çerçevesinde tahsis edilen yardımların dağıımı için, A.B.D. bünyesinde Ekonomik Iş̧irliği Idaresi (Economic Cooperation Administration, EC A ) adında bir örgüt kuruldu. Bu örgütün onayı olmadan, hiçbir yardım gönderilmeyecek ve kullanılmayacaktı. ECA bir kamu kuruluşu niteliği taşımıyordu. Özel sektör yetkililerinden oluşan ve danışma komiteleri yoluyla ozzel sektờr gruplanyla ilişkilendirilen bir bağımsız ajanstı. ECA'nın özel sektörle böylesine yakın ilişki içinde bulunmasının nedeni, Amerikan şirketlerinin Avrupa pazanna doğrudan girebilmesini sağlamak ve Avrupa'da tek bir pazar oluşumunun önündeki engelleri kaldırmaktır. Buna karşılık, Avrupa ülkeleri de kendi aralarında, Avrupa Ekonomik Işbirliği Örgüttu

${ }^{25}$ Council...,op.cit., s.60.

${ }^{26}$ Senato'daki göriłşmeler sırasında söz alan Senatör Bemard Brauch, Amerika'nın en buyulk sorununun Avrupa'nın yeniden iman değil, yurtiçindeki enflasyonun önlenmesi olduğunu savunuyordu. Brauch, "Ekonomimizi istikrara kavuşturmadığımız sürece global barış stratejimiz bize hiç birşey kazandırmayacakur" şeklinde konuşmaktaydı. ( Bkz. U.S. Congress, Senate, European Recovery Program, Hearing Before the Committee of Foreign Relations, 80. Congress, 2. Session, Jan 16-28 1948; Washington D.C., Governmental Printing Office, 1948, s.559-560.)

${ }^{27}$ De Conde, op. cit., s.677. 
(Organization of European Economic Cooperation, OEEC)'nü kurdular. Bu örgüt ileriki tarihlerde, kamu ve özel sektör temsilcilerinin işbirliği yaparak, ulusal para ve maliye politikalarını düzenleyecekleri, Avrupa istikrarı ve bütünleşmesi için çalışacakları Ekonomik Işbirliği ve Kalkınma Örgütü (Organization of Economic Cooperation and Development, OECD)'ne dönüşecektir. ${ }^{28}$

Marshall Planı çerçevesinde, A.B.D., katılımcı ülkelere 13 milyar dolar civarında yardım yapmıştur.(Bu miktarın ayrıntulan ek tabloda görülmektedir) Yardımlar sonucunda, Amerikan şirketlerinin, 1929-1940 döneminde \%1.5 artan Avrupa yaturımları, 1947-1950 yılları arasında, madencilik sektöründe $\% 38$, sanayi ürünlerinde $\% 58$, petrol ürünlerinde \%143 arımıştır. Bu artı̧̧ sonraki yıllarda da devam etmiş, 1950-1970 döncminde, Amerikan şirketlerinin Latin Amerika'daki yatırımlarındaki aruş \%320, Asya'da \%556 iken, Avrupa'daki tüm yatırımlarındaki arış \%1400 olarak gerçekleşmiştir. Aynı dőnemde Avrupa'da şube açan Amerikan bankalarının sayısı da 6'dan 72'ye çıkmışur.

Marshall programı, gerçekten de Amerikan ekonomisini muhtemel bir durgunluktan kurtarak can simidi olmuştu. Avrupa ckonomileri elbette Plan sayesinde bazı olumlu sinyaller vermeye başlamış̧ı. Ama bundan en büyük karı yine Amerikalılar sağlamışlardır. Şöyle ki, ${ }^{2955}$ 'de, İngiltere'deki ayakkabı fabrikalarının $\% 60$ 'ı, bebek maması, renkli ve siyah-beyaz film, nişasta, dikiş makinesi, daktilo fabrikaların!n \%80'i, kahvaltılık malzeme, hesap makinesi, sigara, patates cipsi, jilet, buji fabrikalarının $\% 65 ' i$, otomobil, süt, kozmetik ürünleri, ilaç, traktör, petrol ürünleri, elcktrikli ev aletleri fabrikalarının \%50'si, lastik, sabun, deterjan, baskı makinası fabrikalarının \%45'i Amerikan sermayesinin yönetimindeydi. Fransa'da ise, A.B.D. firmalan, aynı yıllarda bilgisayar ve entegre ürünlerinin \%80'ini, tarım makinalarının \%65'ini, iletişim makinalarının \%65'ini, film ve fotoğraf kağıtlarının \%70'ini, otomobil ve uçak lastiklerinin $\% 45^{\prime}$ ini, petrol ürünlerinin ise \%40'ının üretmekteydi. Avrupa, Amerikan sermayesi için, neredeyse 19. yüzyıl ortalanındaki "Uzak Batı". háline gelmişti. ${ }^{29}$

Eğer Marshall Yardımlarını, basitçe enflasyonu kontrol etmeyi, ticareti canlandırmayı ve üretimi yeniden başlatmayı amaçlayan bir program olarak görürsck başarılı olduğunu soylememiz mümkündür.1950'ye gelindiğinde; Fransa dışında, katılımcı ülkelerin çoğunda enflasyon düşmüştür. Avrupa içi ve dışı ticaret artmışur. Plan'ın uygulandığı 1948-1953 döneminde, Batı Avrupa'nın toplam GSMH'sı, 120 milyar dolardan \%32 artş̧la 159 milyar dolara, zirai ürctimi savaş öncesinin \%11, sanayi üretimi ise yine savaş öncesinin \%40 üzerine çıkmıştır. Yardımlar, Avrupa'nın kendi kendine yeterli olabilmesi için gerekli ilk hızı vermiş̧tir. Temel maddelerin ithalatı kolaylaşmış, üretimdeki darboğaz aşılmış, dolayısıyla üretim artışı, ticaret gelişmesi ve sosyal banş̧ ve refah să̆lanmışır. ${ }^{30}$

Amerika'nın Plan çerçevesinde verdiği parasal ve tẹknik yardımlar ile çeşitli Avrupa ülkelerinde yapılanlara örnekler verirsek, Hollanda'da sabun ve deterjan fabrikalarında daha önce beş günde yapılabilen bir kimyevi işlem Amerikalıların yardımıyla bir günde yapılır hale gelmiş, Norveç'te balıkçılar ftalya'da Amerikan pamuğundan dokunan yeni balık ağları kullanmaya başlamıs, Almanya'da Offenbach deri

\footnotetext{
28 Idem.

${ }^{29}$ Mee, op. cit., s.258.

${ }^{30}$ Hogan, op. cit., s.430.
} 
fabrikası Amerikan teknisyenleri tarafından revize edilmiş, Danimarka'da kullanılmaya başlayan Amerikan yapımı orrme makinaları trikotaj sektőründe \%10 verim artışı sağlamıs, Avusturya'da, bin öksüz çocuğun bakımlan sağlanmış, Türkiye'de üç yıl içinde sıtmanın kökü kurutulmuştur. Yine yardımlarla, Fransa'nın Lille kentinde, Amerikan parasal ve teknik yardımıyla bir çelik fabrikası kurulmuş, bunu Roubaix'de dünyanın en büyük tekstil fabrikalarından birisinin kurulması izlemiş, savaş sırasında \%70'i tahrip edilen Fransız limanlan 2 yıl içinde restore edilmiş, Fransız ayakkabı ve deri sanayisinde Amerikan tekniklerinin uygulanmasıyla \%20 verim artı̧ı sağlanmış, traktơr sayısı beş yıl içinde dört kat artmış, 1954'de elektrik üretimi Plan öncesinin dört katına çıkmış, sabit \%5 GSMH artışı sağlanmışır. Italya'da ise hammadde eksikliğine rağmen, Plan'ın verdiği hızla otomobil sanayisi gelişmiş, Olivetti fabrikası dünya ticaretinin devleri arasına girmiş, Ingiltere'de de gıda üretimi artmış, bobylece fiyatlar ucuzlamıştı. ${ }^{31}$ (Ancak, sömürgelerini bir bir kaybeden Ingiltere'de, beklenen miktarda ekonomik iyileşme sağlanamamıştr.)

Ekonomik yönlerinin yanısıra, yardımlar siyasi olarak da etkili olmuştur. Italya'ya ilk yardım gemilerinin ulaşmasıyla, siyasal propagandasını komünizm karşıllığına ve Marshall yadımlarına dayandıran Hıristiyan Demokrat Parti seçimi kazanmışur. Başbakan Alcide de Gasperi'ye göre Marshall yardımlanı Italya'nın umudu olmuştur. Kampanyasını Marshall ve Amerikan karşıtlığına dayandıran komünist lider Palmiro Togliatti ise tahmin edilenden çok daha az oy toplayabilmiştir. Fransa'da ise, Planla gelen kaostan kurtulma havası içinde, 1947-52 döneminde hükümetten dışlanmışlardır. Liberal ve ılımlı sol eğilimler sağ kanat partileriyle işbirliği yaparak sağlam koalisyonlàr kurmuşlardır. ${ }^{32}$

Öte yandan 14 Mayıs 1950 seçimleriyle Türkiye'de iktidara gelen Demokrat Parti, yoğun Amerikan yardımı sayesinde, tarımsal üretimde bir patlama sağlamış, köylüyü memnun ederek 1954 seçimlerinde oy oranını artırmışır.

Bu arada, Plan'ın uygulanmasıyla, dört bölgeli işgal Almanya'sı, Sovyetler ve Batılılar arasında ikiye bölünmüştür. 1948 sonbaharı ve 1949 ilkbaharında Bonn'da biraraya gelen Batı Alman siyasi liderleri yeni demokratik bir anayasa oluşturmak için çalışmalara başlamışlardır. Tabii ki, işgal güçlèri bu süreci yakından izlediler ve telkinlerde bulundular. 73 yaşındaki Başbakan Konrad Adenauer, her hafta parlamentonun aldığı kararlan Ren nehrinin batı yakasındaki Petersberger Hof şatosunda bulunan mütuefik yüksek komiserlerine sunuyor ve onlanın görüş ve tavsiyelerini alıyordu.

Marshall yardimlarının etkisiyle, yeni Almanya, Wirtshaftswunder denilen bir ekonomik mucize gerçckleş̧irmiştir. Doğu topraklan Sovyetlerce koparılan ve tarımsal alt yapısının büyük bölümü yok olmuş olan bu ülkede, 1949-51 döneminde dış ticaret hacmi iki katına çıkmıştır. 1951'de ihracat \%75 artı. Bu aruş 1954-1964 döneminde artarak devam etmiştir. 1948-1964 döneminde sanayi üretimi altu kat artarken, işsizlik $\% 9$ 'dan \%0.4'e düşmüştür. 1946 'da iki milyon ton olan çelik üretimi, 1949 'da dokuz milyon tona çıkt. 1953 'de ise bu miktar 19.5 milyon tona ulaşt. Mercedes, Opel, Volkswagen gibi otomobil üreticileri üretimlerini iki kat artırmıştır. ${ }^{33}$

\footnotetext{
31 Mee, op. cit., s.251.

32 Ibld., s.255.

${ }^{33}$ Hogan, op. cit., s.435.
} 
Ancak Marshall yardımlarının, Avrupa'ya aktarılması, Soğuk Savaş'ın şiddetlenmesiyle giderek azalmışur. Çünkü, ozellikle 25 Haziran 1950'de Kuzey Kore'nin Güney Kore'yi işgaliyle başlayan Kore Savaşı(ndan sonra, A.B.D.'nin savunma harcamaları hızla artmıştur. Bu durumda, Avrupa'ya aktarılan yardımlar azala azala sona ermiştir. Zaten 1949'da NATO'nun kurulmasıyla, Bau Avrupa'da Amerika'nın liderliğinde bir askeri blok oluşturulmuş̧u. Kore Savaşı'nın başlamasıyla, Avrupa'ya yőnelik ekonomik yardımlar, askeri yardımlara dönü̧̧̧̋̈rüldü ve NATO şerçevesinde verilmeye başladi. Marshall Planı da 1953'te resmen sona erdirildi. ${ }^{34}$

Plan sona erdiğinde, aralanndaki sorunlar daha onceye nispetle hayli azalmıs, tek bir ortak pazar kurmanın yararlarına inanmış, işbirlił̧ine açık bir Batı Avrupa yaratulmışu. Bu ülkeler, günümüzdeki ismiyle "Avrupa Birliği"ne giden yolu artuk kendi çabalanyla oluşturmuşlardır. Ancak, bu süreçte Marshall Yardımlan yoluyla A.B.D.'nin verdiği ilk hiz da unutulmamalıdrr.

34 William Mc Neil, Iuunnya Tarlhi, (çev. Alaattin Şenel), Ankara, Imge, 1994, s.573. 
Marshall Planı Yoluyla Verilen Yardımlar (Milyon Dolar)

\begin{tabular}{lrrrr} 
ÜUke & Toplam & \multicolumn{1}{c}{$\%$} & Hihe & \multicolumn{1}{c}{$\%$} \\
Toplam & $12.992,5$ & 100,0 & $9.290,2$ & 100,0 \\
Ingiltere & 3.165 .8 & 24,4 & $1.956,9$ & 21,0 \\
Fransa & $2.629,8$ & 20,2 & $2.212,1$ & 23,8 \\
ttalya & $1.434,6$ & 11,0 & $1.174,4$ & 12,6 \\
B.Almanya & $1.317,3$ & 10,1 & $1.078,7$ & 11,6 \\
Hollanda & $1.078,7$ & 8,3 & 796,4 & 8,6 \\
Avusturya & 653,8 & 5,0 & 556,1 & 6,0 \\
Yunanistan & 628,0 & 4,8 & 34,4 & 5,5 \\
Belçika & 546,6 & 4,2 & 217,3 & 0,3 \\
Danimarka & 266,4 & 2,1 & 196,0 & 2,3 \\
Norvef & 241,9 & 1,9 & 62,4 & 2,1 \\
Türkiye & 184,5 & 1,4 & 18,0 & 0,7 \\
trlanda & 146,2 & 1,1 & - & 0,2 \\
tsvef & 107,1 & 0,8 & $.5,5$ & - \\
Portekiz & 50,5 & 0,4 & 15,9 & 0,1 \\
Ispanya & 26,8 & 0,2 & - & 0,2
\end{tabular}

